\title{
Spatial distribution and habitat suitability of Biomphalaria straminea, intermediate host of Schistosoma mansoni, in Guangdong, China
}

Ya Yang ${ }^{1 \dagger}$, Shao-Yu Huang ${ }^{2 \dagger}$, Fu-Quan Pei ${ }^{2}$, Yue Chen ${ }^{3}$, Qing-Wu Jiang ${ }^{1}$, Zhuo-Hui Deng ${ }^{2^{*}}$ and Yi-Biao Zhou ${ }^{1 *}$

\begin{abstract}
Background: Biomphalaria straminea is an invasive vector in China, posing a significant threat to public health. Understanding the factors affecting the establishment of this snail is crucial to improve our ability to manage its dispersal and potential risk of schistosomiasis transmission. This study sought to determine the spatial distribution of $B$. straminea in mainland China and whether environmental factors were divergent between places with and without B. straminea.

Methods: A malacological survey of B. straminea was conducted in Guangdong Province, China. Snails were identified using anatomical keys. Water and sediment samples were taken, and their physicochemical properties were analyzed using national standard methods. Landscape and climatic variables were also collected for each site. We compared the environmental characteristics between sites with and without B. straminea using Mann-Whitney $U$ test. We further used generalized linear mixed models to account for seasonal effects.

Results: $B$. straminea was found at six sites, including one in Dongguan and five in Shenzhen. Probability map found a hot spot of B. straminea distribution at Shenzhen and Hong Kong. Sites occupied by B. straminea were characterized by higher median altitude, mean annual precipitation and moderate temperature. Water with snails had higher median concentrations of total nitrogen, nitrate and nitrites, ammoniacal nitrogen, calcium, zinc and manganese but lower dissolved oxygen and magnesium. Sediments with snails had higher median copper, zinc and manganese. B. straminea was associated with maximum temperature of the warmest month ( $\mathrm{pMCMC}<0.001)$ and sediment zinc (pMCMC < 0.001).

Conclusions: B. straminea is distributed in Shenzhen and its surrounding areas in Guangdong, China. Sites with and without $B$. straminea differed in the maximum temperature of the warmest month and sediment zinc. Surveillance should be continued to monitor the dispersal of this snail in China.
\end{abstract}

Keywords: Biomphalaria straminea, Distribution, Environmental factor, Guangdong, China

\footnotetext{
*Correspondence: tracydzh@163.com; z_yibiao@hotmail.com

${ }^{\dagger}$ Ya Yang and Shao-Yu Huang contributed equally to this work.

${ }^{2}$ Guangdong Provincial Center for Disease Control and Prevention, WHO

Collaborating Centre for Surveillance, Research and Training of Emerging

Infectious Diseases, Guangzhou, Guangdong, China

${ }^{1}$ Key Laboratory of Public Health Safety, Ministry of Education, Tropical

Disease Research Center, Department of Epidemiology, School of Public

Health, Fudan University, Shanghai, China

Full list of author information is available at the end of the article
}

(c) The Author(s). 2018 Open Access This article is distributed under the terms of the Creative Commons Attribution 4.0 International License (http://creativecommons.org/licenses/by/4.0/), which permits unrestricted use, distribution, and reproduction in any medium, provided you give appropriate credit to the original author(s) and the source, provide a link to the Creative Commons license, and indicate if changes were made. The Creative Commons Public Domain Dedication waiver (http://creativecommons.org/publicdomain/zero/1.0/) applies to the data made available in this article, unless otherwise stated. 


\section{Multilingual Abstract}

Please see Additional file 1 for translations of the Abstract into the five official working languages of the United Nations.

\section{Background}

Schistosomiasis is one of the most widespread human parasitic diseases, affecting more than 200 million people worldwide [1, 2]. Schistosoma mansoni, whose intermediate hosts are freshwater snails of the genus Biomphalaria, is estimated to infect more than 80 million people in the tropical and subtropical areas of Africa, the Middle East, and South America [3]. Although S. mansoni is not currently endemic in China, imported schistosomiasis cases of such kind have been continuously reported in laborers returned from Africa [4].

The transmission of schistosomiasis is determined by the existence and geographic distribution of its host snails [5]. Biomphalaria straminea is an intermediate host of $S$. mansoni and is originated in southeastern South America [6]. B. straminea has gradually expanded its habitats to other states of Brazil and surrounding countries, which are attributed to its capacity to endure long periods of drought and greater fertility $[3,4]$. In addition to the above peripheral range extensions, $B$. straminea is known for intercontinental dispersal to Hong Kong of China in 1974, possibly through tropical aquarium plants or fish trade with South America [7]. Since then, the snail has been found in different water habitats in Hong Kong and Shenzhen, Dongguan, and Huizhou of Guangdong Province, China [3, 8].

In the context of globalization, especially with the advent of China's Belt and Road Initiative [9], growing movement of goods and people could increase the risk of transmission of $S$. mansoni in China in the presence of $B$. straminea snails. Therefore, there was an urgent need to determine the spatial distribution of B. straminea in China. B. straminea has established in various freshwater habitats in Hong Kong but no evidence of S. mansoni was found in the snails [10]. However, there is currently a lack of large-scale, comprehensive snail survey in mainland China. Moreover, previous studies have shown that environmental and ecological factors, including temperature, light, water chemistry and conductivity and aquatic vegetation, can influence the distribution and abundance of Biomphalaria snails $[6,11]$. The purpose of this study was to determine the spatial distribution of B. straminea in mainland China and whether environmental factors differ between places with and without $B$. straminea.

\section{Methods}

Study area

Guangdong Province, located in southeast China, consists of twenty-one prefecture-level divisions. This region experiences a subtropical monsoon climate, featuring hot and humid summers, and mild winters. The averages of annual temperature and annual precipitation are $21.8{ }^{\circ} \mathrm{C}$ and $1789.3 \mathrm{~mm}$, respectively. Guangdong has extended water systems. Generally, these rivers can be divided into the Pearl River (including three upstream rivers: the East River, North River, and West River), the Han River and other minor rivers along the coast.

\section{Study design}

One hundred and eighty-seven study sites were from 11 municipals (Shenzhen, Zhanjiang, Yangjiang, Jiangmen, Guangzhou, Dongguan, Huizhou, Shanwei, Zhaoqing, Qingyuan, and Shaoguan) of Guangdong Province (see Fig. 1). These sites were selected based on the presence of aquatic habitats, accessibility along the Pearl River and its tributaries and existence of B. straminea reported by previous studies. Swamps and puddles adjacent to the river and streams were also sampled. Given the considerable area of Guangdong, the sampling events carried out during November 2016 to October 2017. Each site was surveyed once at approximately the same time of day, in order to make comparisons. The sampling sites were coded based on location and point of sampling. The geographic coordinates of each site were recorded with a handheld Global Positioning System (GPS) device (Trimble Navigation Inc., Sunnyvale, USA).

\section{Snail sampling}

Predefined protocols were used for the snail survey [12]. In brief, sampling was carried out by two trained field investigators with a scoop. At each site, the permitted sampling time was $30 \mathrm{~min}$. Any snail in a radius of approximately $2 \mathrm{~m}$ was captured. All collected snails were labeled, transferred to the laboratory and identified using anatomical keys including the shape of shells and the number of prostate diverticula [6].

\section{Water and sediment analysis}

The samples were collected on sunny or cloudy days to minimize the effects of weather conditions. Surface water samples were collected at $20 \mathrm{~cm}$ depth using polyethylene plastic bottles. The bottles were triple rinsed with sample water prior to collection. Surface sediments $(0-10 \mathrm{~cm})$ were collected at the edge of the bank, where the snails are most likely to be present, using a plastic shovel. Sediments were stored in pre-rinsed polyethylene plastic bottles. Water and sediment samples were clearly labeled with the location name. GPS coordinates, time and date of survey. Water and sediment samples were 


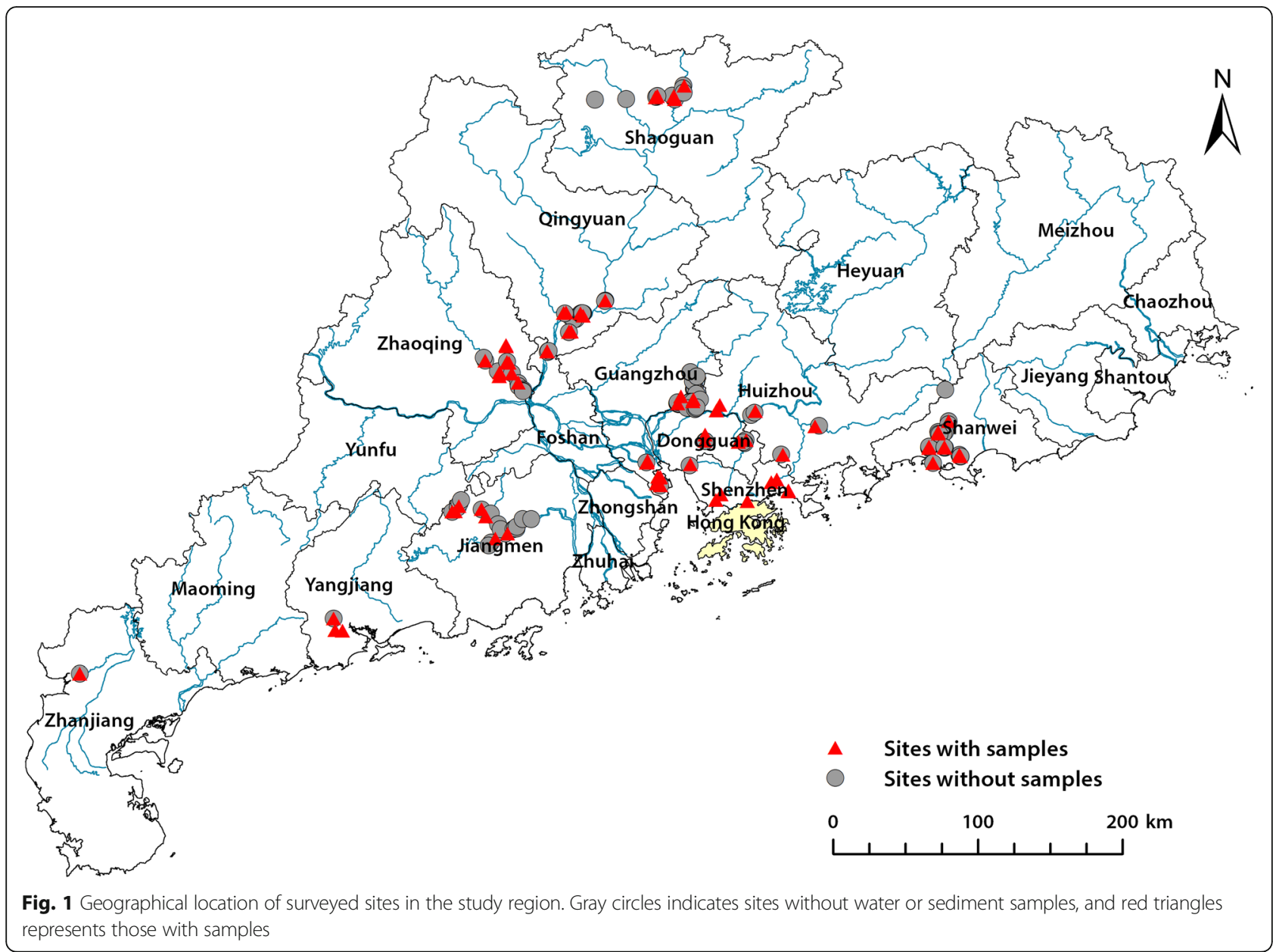

kept refrigerated and delivered to the laboratory within 2-5 days of collection. Water samples were measured for $\mathrm{pH}$, electrical conductivity (EC) and the concentrations of total nitrogen $(\mathrm{TN})$, nitrate and nitrites $\left(\mathrm{NO}_{\mathrm{x}-}\right)$, ammonia nitrogen $\left(\mathrm{NH}_{3-} \mathrm{N}\right)$, total phosphorus (TP), chemical oxygen demand (COD), dissolved oxygen $(\mathrm{DO})$, calcium $(\mathrm{Ca})$, magnesium $(\mathrm{Mg})$, copper $(\mathrm{Cu})$, zinc $(\mathrm{Zn})$, iron $(\mathrm{Fe})$, manganese $(\mathrm{Mn})$, cadmium $(\mathrm{Cd})$, lead $(\mathrm{Pb})$, chromium $(\mathrm{Cr})$ and nickel $(\mathrm{Ni})$. Sediments were measured for $\mathrm{pH}, \mathrm{EC}$, total organic carbon (TOC) and the concentrations of $\mathrm{Cu}, \mathrm{Zn}, \mathrm{Fe}, \mathrm{Mn}, \mathrm{Cd}, \mathrm{Pb}, \mathrm{Cr}$, and $\mathrm{Ni}$. The detailed methods, instruments, and limits of detection (LOD) of each analysis can be found in the supplementary material (Additional file 2).

\section{Landscape and climatic data}

We used mean annual precipitation (MAP, $\mathrm{mm}$ ), mean annual temperature (MAT, ${ }^{\circ} \mathrm{C}$ ), maximum temperature of warmest month (MaxTWM, $\left.{ }^{\circ} \mathrm{C}\right)$, minimum temperature of coldest month (MinTCM, ${ }^{\circ} \mathrm{C}$ ), mean temperature of warmest quarter (MTWQ, ${ }^{\circ} \mathrm{C}$ ) and mean temperature of coldest quarter (MTCQ, ${ }^{\circ} \mathrm{C}$ ) from WorldClim version 2.0, which uses historic global meteorological station data from 1970 to 2000 to interpolate global climate surfaces [13]. The spatial resolution of this climate surface is $30 \mathrm{~s}$ (approximately $1 \mathrm{~km}^{2}$ ). We extracted the variables for each sampling site according to the latitude and longitude.

We extracted the altitude of each site from the $30 \mathrm{~m}$ Shuttle Radar Topography Mission (SRTM) data. To analyze the association between the presence of $B$. straminea and vegetation canopy cover, we used mean annual normalized difference vegetation index (NDVI) values, extracted from the $1 \mathrm{~km} \times 1 \mathrm{~km}$ resolution SPOT-VEGETATION NDVI layers for years 2011 through 2015. This mean NDVI product is a proxy for the level of living green plant canopies over a year. The $30 \mathrm{~m}$ SRTM and NDVI data sets are from by Data Center for Resources and Environmental Sciences, Chinese Academy of Sciences (RESDC) (http://www.resdc.cn).

\section{Statistical analysis}

We calculated descriptive statistics for environmental variables. The relationships among variables were analyzed using Spearman's rank correlations test and were visualized using corrplot package [14]. The Mann-Whitney $U$ test was used to test the heterogeneity of 
environmental and physicochemical characteristics for sites with and without $B$. straminea.

We first estimated the relationship between the presence of B. straminea (as a binary response variable) and environmental and physicochemical variables by fitting generalized linear mixed model (GLMM). The models were limited to variables with at least $50 \%$ of concentrations above LOD. Measurements below LODs were assigned one-half of the LOD values. Normality of variables was determined with visual inspection of data, and $\log 10$ transformation was used when necessary. Site code and survey month were used as random effects to account for the seasonal effects on the measurements and between site variability. The GLMM was built using Markov Chain Monte Carlo (MCMC) in the R package MCMCglmm [15]. For each model, the MCMC chains were run for 50000 iterations with a burn-in of 10000 and thinning interval of 20, to get posterior sample sizes of 2000. We fitted models that included significant variables from the univariate GLMMs and used backward selection to identify the minimal adequate model that retained only significant variables. All pairwise correlations between the included predictors were lesser than 0.40 . We summarized parameter estimates using posterior means and $95 \%$ credible intervals $(C I)$. A significance level of 0.05 was used for all tests. All analyses were done using $\mathrm{R}$ software (version 3.4.1, The $\mathrm{R}$ Project for Statistical Computing, https://www.r-project.org/).

We obtained additional occurrence data of $B$. straminea from a recent survey in Hong Kong during 2016-2017, which used similar snail sampling and identification methods to our study [10]. These presence points, together with data of our own survey, were spatially interpolated using Empirical Bayesian Kriging (EBK) in ArcGIS 10.2.2 (Environmental Systems Research Institute, Inc., Redlands, USA) to predict the spatial distribution of $B$. straminea in China [16]. Default general settings were used in the process of EBK.

\section{Results}

\section{Spatial distribution of $B$. straminea}

Biomphalaria straminea was found at 6 sites, including 1 in Dongguan and 5 in Shenzhen during 2016-2017 (Fig. 2a). A hot spot for the distribution of B. straminea was found at the areas around Shenzhen and Hong Kong (Fig. 2b).

\section{Environmental and physicochemical characteristics}

The altitude of sites ranged from minus $8 \mathrm{~m}$ to $190 \mathrm{~m}$ (Table 1). Most of the sites were well vegetated, with NDVI values over 0.6. Mean annual precipitation ranged from $1485.0 \mathrm{~mm}$ to $2106.0 \mathrm{~mm}$, and the mean annual temperature showed values from $19.1{ }^{\circ} \mathrm{C}$ to $23.1{ }^{\circ} \mathrm{C}$.
Other temperature-related variables are also summarized in Table 1.

The water and sediment chemistry properties are shown in Table 2. Water $\mathrm{pH}$ values varied from 4.91 to 7.78. The mean concentrations of $\mathrm{TN}, \mathrm{NO}_{\mathrm{x}}{ }^{-}$and $\mathrm{NH}_{3}$ $\_\mathrm{N}$ were $10.40 \mathrm{mg} / \mathrm{L}, 1.66 \mathrm{mg} / \mathrm{L}$, and $1.11 \mathrm{mg} / \mathrm{L}$, respectively, with $\mathrm{NH}_{3} \mathrm{~N}$ showing the highest variability. The TP concentration ranged from $0.01 \mathrm{mg} / \mathrm{L}(<\mathrm{LOD})$ to $3.47 \mathrm{mg} / \mathrm{L}$. The mean COD and DO concentrations were $14.59 \mathrm{mg} / \mathrm{L}$ and $5.25 \mathrm{mg} / \mathrm{L}$. Electrical conductivity ranged from $68.85 \mathrm{mS} / \mathrm{m}$ to $1677 \mathrm{mS} / \mathrm{m}$. The average $\mathrm{Ca}, \mathrm{Mg}, \mathrm{Zn}, \mathrm{Fe}$ and $\mathrm{Mn}$ concentrations were $18.51 \mathrm{mg} / \mathrm{L}$, $1.10 \mathrm{mg} / \mathrm{L}, 0.14 \mathrm{mg} / \mathrm{L}, 0.81 \mathrm{mg} / \mathrm{L}$ and $0.27 \mathrm{mg} / \mathrm{L}$, respectively. Over half $\mathrm{Cu}(54.1 \%)$ and $\mathrm{Ni}(73.8 \%)$ measurements were below LODs. All water $\mathrm{Cd}, \mathrm{Pb}$, and $\mathrm{Cr}$ were below LODs.

The $\mathrm{pH}$ for sediments was from 3.94 to 8.28 . The average TOC was $30.33 \mathrm{~g} / \mathrm{Kg}$. The average $\mathrm{Cu}, \mathrm{Zn}, \mathrm{Fe}, \mathrm{Mn}$, $\mathrm{Cd}$ and $\mathrm{Pb}$ concentrations in sediment were $4.46 \mathrm{mg} / \mathrm{kg}$, $16.52 \mathrm{mg} / \mathrm{kg}, 260.63 \mathrm{mg} / \mathrm{L}, 87.059 \mathrm{mg} / \mathrm{kg}, 0.23 \mathrm{mg} / \mathrm{kg}$, $6.50 \mathrm{mg} / \mathrm{kg}$ and $3.17 \mathrm{mg} / \mathrm{kg}$, respectively. Ni measurements varied from < LOD to $34.37 \mathrm{mg} / \mathrm{kg}$. $97.3 \%$ of sediment samples had $\mathrm{Cr}$ concentration below LOD.

\section{Relationships among environmental and physicochemical variables}

Altitude showed a positive correlation with NDVI and negative correlations with climatic variables (MAT, MinTCM, MTWQ and MTCQ) except for MAP and MaxTWM (Fig. 3). NDVI showed significant negative correlation with MAT, MinTCM, and MTCQ. MAP was positively correlated with MAT, MinTCM, and MTCQ but was negatively correlated with DO. MaxTWM was negatively correlated with MinTCM and Mg. TN showed positive correlations with $\mathrm{NO}_{\mathrm{x}}{ }^{-}, \mathrm{COD}, \mathrm{Zn}$ and $\mathrm{Mn}$. $\mathrm{NH}_{3} \mathrm{~N}$ was positively correlated with $\mathrm{Ca}$. TP was negatively related to $\mathrm{DO}$. Moreover, $\mathrm{Cu} \_\mathrm{s}$ showed significant positive correlations with $\mathrm{Mn} \_\mathrm{S}$ and Ni_s. Mn_S was also positively related to Ni_s.

\section{Differences between sites with and without $B$. straminea}

Sites where $B$. straminea had higher altitude, mean annual precipitation, MinTCM and MTCQ, and lower MaxTWM and MTWQ (Table 3). TN, $\mathrm{NO}_{\mathrm{x}}{ }^{-}, \mathrm{NH}_{3-} \mathrm{N}$, $\mathrm{Ca}, \mathrm{Zn}$ and $\mathrm{Mn}$ concentrations were higher in water samples with $B$. straminea snails, however, the DO and $\mathrm{Mg}$ were lower. For sediments, $\mathrm{Zn}$ was found to be higher at sites with snails (Table 3).

\section{Results of univariate and multivariate GLMM}

Univariate GLMM found that presence of B. straminea was associated with NDVI (pMCMC $=0.007$ ), MaxTWM $(\mathrm{pMCMC}=0.024)$, water $\mathrm{DO}(\mathrm{pMCMC}=0.001)$, water $\mathrm{Mg} \quad(\mathrm{pMCMC}<0.001)$ and sediment $\log 10\left(\mathrm{Zn} \_\mathrm{s}\right)$ 


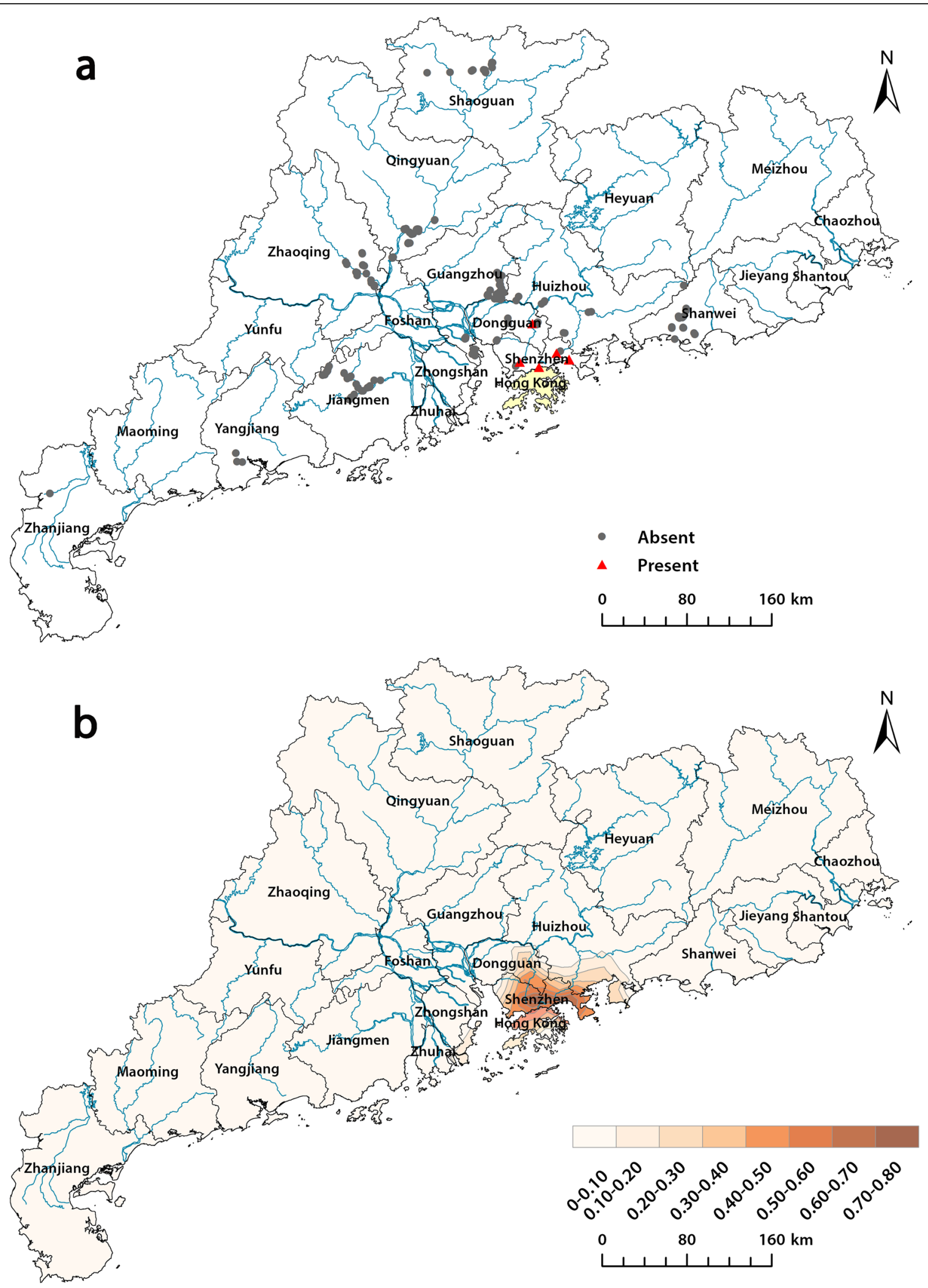

Fig. 2 Geographical distribution of the survey sites (a) and probability map of the B. straminea snails in China (b). Probability map was built using presence data from our study and a survey in Hong Kong 
Table 1 Distributions of landscape and climatic characteristics of surveyed sites

\begin{tabular}{|c|c|c|c|c|c|c|c|c|}
\hline Variables & Min & $25 \%$ & $50 \%$ & $75 \%$ & $\operatorname{Max}$ & Mean & SD & $\mathrm{CV}$ \\
\hline Altitude (m) & -8.0 & 2.0 & 9.0 & 36.0 & 190.0 & 26.2 & 39.7 & 1.52 \\
\hline NDVI & 0.2 & 0.6 & 0.7 & 0.8 & 0.9 & 0.6 & 0.1 & 0.22 \\
\hline Mean annual precipitation (MAP, mm) & 1485.0 & 1695.0 & 1718.0 & 1845.0 & 2106.0 & 1771.4 & 156.2 & 0.09 \\
\hline Mean annual temperature $\left(\mathrm{MAT},{ }^{\circ} \mathrm{C}\right)$ & 19.1 & 22.0 & 22.2 & 22.4 & 23.1 & 22.1 & 0.7 & 0.03 \\
\hline Maximum temperature of warmest month $\left(\operatorname{MaxTWM},{ }^{\circ} \mathrm{C}\right)$ & 31.5 & 32.6 & 33.1 & 33.7 & 34.2 & 33.1 & 0.7 & 0.02 \\
\hline Minimum temperature of coldest month (MinTCM, ${ }^{\circ} \mathrm{C}$ ) & 5.0 & 9.9 & 10.7 & 11.7 & 12.8 & 10.6 & 1.6 & 0.15 \\
\hline Mean temperature of warmest quarter $\left(\mathrm{MTWQ},{ }^{\circ} \mathrm{C}\right)$ & 27.2 & 28.2 & 28.5 & 28.6 & 28.8 & 28.4 & 0.3 & 0.01 \\
\hline Mean temperature of coldest quarter $\left(\mathrm{MTCQ},{ }^{\circ} \mathrm{C}\right)$ & 9.8 & 14.3 & 14.9 & 15.3 & 16.3 & 14.6 & 1.3 & 0.09 \\
\hline
\end{tabular}

SD Standard deviation, $C V$ Coefficient of variation, NDVI normalized difference vegetation index

Table 2 Distributions of measured water and sediment parameters in sampled sites

\begin{tabular}{|c|c|c|c|c|c|c|c|c|c|c|}
\hline & N & $n(\%)<\mathrm{LOD}$ & Min & $25 \%$ & $50 \%$ & $75 \%$ & Max & Mean & SD & $\mathrm{CV}$ \\
\hline \multicolumn{11}{|l|}{ Water variables } \\
\hline $\mathrm{pH}$ & 84 & $0(0)$ & 6.69 & 4.91 & 6.48 & 6.72 & 7.02 & 7.78 & 0.58 & 0.07 \\
\hline Total nitrogen (TN, mg/L) & 84 & $0(0)$ & 0.31 & 1.29 & 2.72 & 9.05 & 62.38 & 10.40 & 16.54 & 1.59 \\
\hline Nitrate and nitrites $\left(\mathrm{NO}_{x}^{-}, \mathrm{mg} / \mathrm{L}\right)$ & 84 & $1(1.2)$ & $<L O D$ & 0.32 & 0.81 & 1.9 & 12.22 & 1.66 & 2.38 & 1.43 \\
\hline Ammoniacal nitrogen $\left(\mathrm{NH}_{3} \_\mathrm{N}, \mathrm{mg} / \mathrm{L}\right)$ & 84 & $16(19)$ & $<L O D$ & 0.10 & 0.38 & 1.12 & 10.81 & 1.11 & 2.03 & 1.83 \\
\hline Total phosphorus (TP, mg/L) & 84 & $1(1.2)$ & $<$ LOD & 0.07 & 0.14 & 0.24 & 3.47 & 0.25 & 0.46 & 1.84 \\
\hline Chemical oxygen demand (COD, mg/L) & 84 & $10(11.9)$ & $<L O D$ & 4.94 & 10.18 & 21.71 & 62.75 & 14.59 & 13.07 & 0.9 \\
\hline Dissolved oxygen (DO, mg/L) & 84 & $0(0)$ & 0.01 & 4.63 & 5.53 & 6.37 & 8.51 & 5.25 & 1.75 & 0.33 \\
\hline Electrical conductivity $(E C, \mathrm{mS} / \mathrm{m})$ & 84 & $0(0)$ & 8.47 & 68.85 & 135.95 & 224.75 & 1677 & 199.63 & 266.31 & 1.33 \\
\hline Calcium (Ca, mg/L) & 84 & $2(2.4)$ & $<L O D$ & 1.18 & 5.04 & 21.78 & 202.51 & 18.51 & 35.58 & 1.92 \\
\hline Magnesium (Mg, mg/L) & 84 & $4(4.8)$ & $<L O D$ & 0.66 & 1.10 & 1.53 & 3.15 & 1.10 & 0.65 & 0.59 \\
\hline Copper (Cu, mg/L) & 74 & $40(54.1)$ & $<L O D$ & $<L O D$ & $<\mathrm{LOD}$ & 0.05 & 0.1 & 0.04 & 0.02 & 0.56 \\
\hline Zinc (Zn, mg/L) & 74 & $27(36.5)$ & $<\mathrm{LOD}$ & $<L O D$ & 0.01 & 0.05 & 1.52 & 0.14 & 0.32 & 2.29 \\
\hline Iron (Fe, mg/L) & 56 & $6(10.7)$ & $<L O D$ & 0.17 & 0.44 & 1.02 & 5.34 & 0.81 & 1.01 & 1.25 \\
\hline Manganese (Mn, mg/L) & 74 & $2(2.7)$ & $<\mathrm{LOD}$ & 0.05 & 0.14 & 0.27 & 1.86 & 0.27 & 0.37 & 1.37 \\
\hline Cadmium (Cd, mg/L) & 84 & $84(100)$ & $<L O D$ & $<\mathrm{LOD}$ & $<\mathrm{LOD}$ & $<\mathrm{LOD}$ & $<L O D$ & - & - & - \\
\hline Lead (Pb, mg/L) & 84 & $84(100)$ & $<L O D$ & $<\mathrm{LOD}$ & $<\mathrm{LOD}$ & $<L O D$ & $<L O D$ & - & - & - \\
\hline Chromium (Cr, mg/L) & 84 & $84(100)$ & $<L O D$ & $<L O D$ & $<\mathrm{LOD}$ & $<L O D$ & $<L O D$ & - & - & - \\
\hline Nickel (Ni, mg/L) & 84 & $62(73.8)$ & $<\mathrm{LOD}$ & $<L O D$ & $<\mathrm{LOD}$ & 0.03 & 0.12 & 0.03 & 0.03 & 1.14 \\
\hline \multicolumn{11}{|l|}{ Sediment variables } \\
\hline $\mathrm{pH}$ & 74 & $0(0)$ & 3.94 & 6.64 & 6.97 & 7.31 & 8.28 & 6.84 & 0.7 & 0.1 \\
\hline Electrical conductivity (EC, mS/m) & 74 & $0(0)$ & 27.65 & 217.6 & 435 & 857.83 & 4685.8 & 676.29 & 817.11 & 1.21 \\
\hline Total organic carbon (TOC, g/kg) & 75 & $0(0)$ & 16.22 & 20.29 & 27.41 & 38.21 & 71.08 & 30.33 & 11.62 & 0.38 \\
\hline Copper (Cu, mg/Kg) & 71 & $15(21.1)$ & $<\mathrm{LOD}$ & 0.13 & 1.04 & 3.28 & 107.27 & 4.68 & 13.82 & 2.95 \\
\hline Zinc (Zn, mg/kg) & 71 & $20(28.2)$ & $<\mathrm{LOD}$ & $<\mathrm{LOD}$ & 7.57 & 25.73 & 93.79 & 16.52 & 20.23 & 1.22 \\
\hline Iron (Fe, mg/L) & 64 & $21(32.8)$ & $<L O D$ & $<L O D$ & 298.54 & 340.8 & 675.12 & 260.63 & 184.35 & 0.71 \\
\hline Manganese $(\mathrm{Mn}, \mathrm{mg} / \mathrm{kg})$ & 71 & $10(14.1)$ & $<L O D$ & 0.6 & 75.83 & 139.75 & 600.8 & 87.05 & 92.78 & 1.07 \\
\hline Cadmium (Cd, mg/kg) & 75 & $22(29.3)$ & $<\mathrm{LOD}$ & $<\mathrm{LOD}$ & 0.12 & 0.19 & 3.61 & 0.23 & 0.51 & 2.22 \\
\hline Lead ( $\mathrm{Pb}, \mathrm{mg} / \mathrm{kg})$ & 75 & $5(6.7)$ & $<L O D$ & 0.04 & 1.92 & 8.00 & 72.34 & 6.50 & 12.51 & 1.92 \\
\hline Chromium (Cr, mg/kg) & 75 & $73(97.3)$ & $<L O D$ & $<L O D$ & $<\mathrm{LOD}$ & $<L O D$ & 4.69 & - & - & - \\
\hline Nickel (Ni, mg/kg) & 75 & $56(74.7)$ & $<L O D$ & $<\mathrm{LOD}$ & $<\mathrm{LOD}$ & 1.98 & 34.37 & 2.76 & 4.44 & 1.61 \\
\hline
\end{tabular}




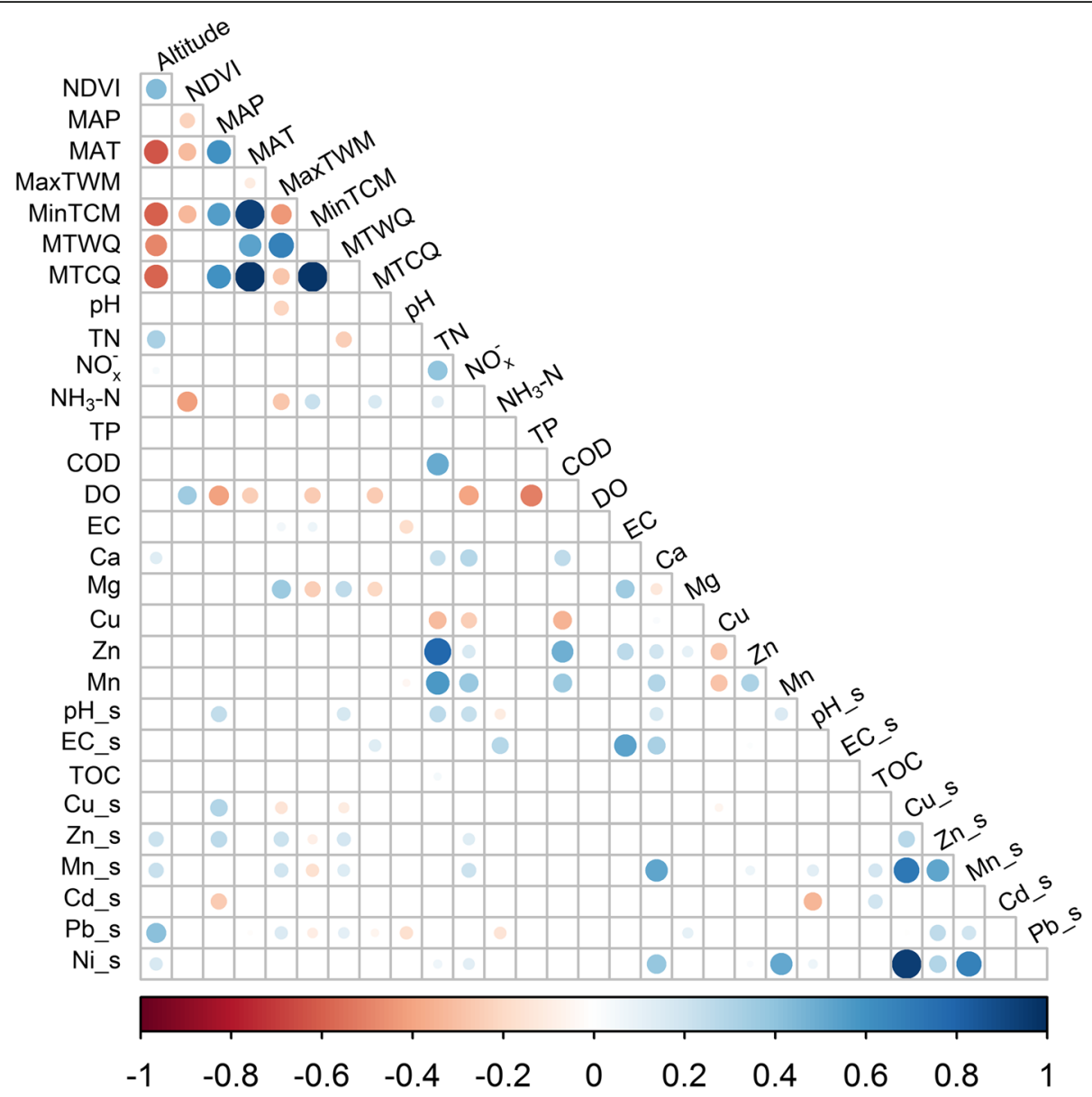

Fig. 3 Spearman rank correlation matrix for environmental and physicochemical variables. The size of the circles indicates the magnitude of the correlation, the color represents the direction of the relationship and presence indicates $P<0.05$. The suffixes, "_s", indicate sediment measurements

$(\mathrm{pMCMC}=0.024) \quad($ Table 4$)$. However, only MaxTWM (pMCMC < 0.001$)$ and sediment $\log 10\left(\mathrm{Zn} \_\mathrm{s}\right)(\mathrm{pMCMC}$ $<0.001$ ) were retained in the final model (Table 5).

\section{Discussion}

This study has been the most systematic and comprehensive attempt to elucidate the geographical distribution of B. straminea in mainland China. B. straminea snails had expanded their range from Shenzhen to its neighboring Dongguan and Huizhou, which was in agreement with previous observations $[3,8]$. The existence of $B$. straminea is a prerequisite for the transmission of $S$. mansoni and has stirred up concerns about the outbreak of this disease in southern China. Schistosomiasis is an important travel-associated infection and frequently reported among returnees from endemic areas. In Europe, 1465 cases of imported schistosomiasis were reported between 1997 and 2010, 95\% of which were acquired from the African continent [17]. An outbreak of urogenital schistosomiasis was reported in Corsica, France, where Bulinus truncatus, a compatible intermediate snail host for schistosome species in West Africa, were present [5]. Given the wide distribution of B. truncatus in southern Europe and the recent increase in migration from endemic areas, the risk of urogenital schistosomiasis has raised many concerns. Since the 1970s when China's aid projects in Africa first started, population and goods movements have been on the increase. It was estimated that there are approximately 1 million Chinese living in Africa. Imported cases of Schistosomiasis mansoni or haematobium have been repeatedly reported among these returnees from African countries [4, 18]. People infected with African schistosomiasis can be misdiagnosed outside of endemic countries. There is also an increase of Africans coming to China for trade, education or travel. For instance, approximately 16000 legal African residents lived in Guangzhou, a city near Shenzhen, in 2014 [18]. Their infection status remains largely unclear to this day. Although there is no record of $S$. mansoni transmission in China so far, the results of this study are informative for the efficient surveillance, control of the intermediate 
Table 3 Comparison of environmental and physicochemical characteristics between sites with and without $B$. straminea

\begin{tabular}{|c|c|c|c|}
\hline & \multicolumn{2}{|c|}{ Presence of $B$. straminea } & \multirow[t]{2}{*}{$P$-value } \\
\hline & No $(n=78)$ & Yes $(n=6)$ & \\
\hline \multicolumn{4}{|c|}{ Landscape and climatic variables } \\
\hline Altitude (m) & $10.0(4.0,33.2)$ & $45.0(43.5,53.2)$ & 0.019 \\
\hline NDVI & $0.7(0.6,0.8)$ & $0.7(0.6,0.7)$ & 0.951 \\
\hline MAP (mm) & $1714(1685,1818)$ & $1969(1937,2016)$ & 0.004 \\
\hline $\operatorname{MAT}\left({ }^{\circ} \mathrm{C}\right)$ & $22.2(22.0,22.3)$ & $22.2(22.0,22.5)$ & 0.807 \\
\hline $\operatorname{MaxTWM}\left({ }^{\circ} \mathrm{C}\right)$ & $33.3(32.9,33.8)$ & $32.4(31.8,32.5)$ & $<0.001$ \\
\hline $\operatorname{MinTCM}\left({ }^{\circ} \mathrm{C}\right)$ & $10.5(9.8,11.4)$ & $11.9(11.7,12.1)$ & 0.009 \\
\hline MTWQ $\left({ }^{\circ} \mathrm{C}\right)$ & $28.5(28.2,28.6)$ & $28.0(27.8,28.3)$ & 0.012 \\
\hline MTCQ $\left({ }^{\circ} \mathrm{C}\right)$ & $14.7(14.1,15.2)$ & $15.2(15.1,15.5)$ & 0.053 \\
\hline \multicolumn{4}{|l|}{ Water variables } \\
\hline $\mathrm{pH}$ & $6.71(6.48,7.05)$ & $6.92(6.52,6.96)$ & 0.889 \\
\hline $\mathrm{TN}(\mathrm{mg} / \mathrm{L})$ & $2.31(1.27,7.80)$ & $8.33(5.79,12.9)$ & 0.030 \\
\hline $\mathrm{NO}_{x}^{-}(\mathrm{mg} / \mathrm{L})$ & $0.78(0.29,1.72)$ & $3.10(1.08,4.53)$ & 0.050 \\
\hline $\mathrm{NH}_{3} \mathrm{~N}(\mathrm{mg} / \mathrm{L})$ & $0.33(0.10,1.04)$ & $2.28(1.23,5.90)$ & 0.025 \\
\hline $\mathrm{TP}(\mathrm{mg} / \mathrm{L})$ & $0.13(0.07,0.20)$ & $0.52(0.17,0.87)$ & 0.071 \\
\hline $\mathrm{COD}(\mathrm{mg} / \mathrm{L})$ & $9.97(4.48,22.1)$ & $14.1(9.32,19.1)$ & 0.487 \\
\hline $\mathrm{DO}(\mathrm{mg} / \mathrm{L})$ & $5.64(4.80,6.51)$ & $3.97(3.62,4.46)$ & 0.039 \\
\hline $\mathrm{EC}(\mathrm{mS} / \mathrm{m})$ & $144(69.4,229)$ & $92.0(68.0,113)$ & 0.234 \\
\hline $\mathrm{Ca}(\mathrm{mg} / \mathrm{L})$ & $4.31(1.01,18.5)$ & $29.2(19.6,104)$ & 0.006 \\
\hline $\mathrm{Mg}(\mathrm{mg} / \mathrm{L})$ & $1.11(0.76,1.57)$ & $0.02(0.01,0.53)$ & 0.002 \\
\hline Zn (mg/L) & $0.01(0.00,0.04)$ & $0.08(0.05,0.19)$ & 0.005 \\
\hline $\mathrm{Mn}(\mathrm{mg} / \mathrm{L})$ & $0.13(0.05,0.26)$ & $0.32(0.25,0.61)$ & 0.010 \\
\hline \multicolumn{4}{|l|}{ Sediment variables } \\
\hline pH_S & $6.98(6.31,7.31)$ & $6.85(6.66,7.15)$ & 1.000 \\
\hline EC_s $(\mathrm{mS} / \mathrm{m})$ & $391(211,814)$ & $962(557,1649)$ & 0.124 \\
\hline TOC (g/kg) & $27.4(20.4,37.8)$ & $28.5(20.3,43.3)$ & 0.907 \\
\hline Cu_s (mg/kg) & $0.67(0.13,2.96)$ & $2.84(1.51,22.5)$ & 0.046 \\
\hline Zn_s (mg/kg) & $5.76(0.20,22.4)$ & $37.7(22.3,48.4)$ & 0.005 \\
\hline Mn_s (mg/kg) & $71.3(0.57,132)$ & $199(81.0,212)$ & 0.020 \\
\hline Cd_s (mg/kg) & $0.13(0.00,0.19)$ & $0.07(0.04,0.18)$ & 0.820 \\
\hline Pb_s (mg/kg) & $1.92(0.04,8.10)$ & $2.76(1.00,4.81)$ & 0.922 \\
\hline $\mathrm{Ni} \_\mathrm{s}(\mathrm{mg} / \mathrm{kg})$ & $1.25(1.25,1.25)$ & $2.22(1.25,10.4)$ & 0.099 \\
\hline
\end{tabular}

Environmental and physicochemical variables are shown as median (25th and 75th percentile)

host and prevention of the introduction and transmission of a new species of Schistosoma in mainland China. Pre-travel health care education and post-travel consultations also proved useful for the prevention of schistosomiasis infection and early detection of asymptomatic infections [17].

B. straminea was first discovered in a stream in Hong Kong in 1974 [7] and in some ponds, ditches, and rivers in Shenzhen city, mainland China in 1981 [8]. More than thirty years later, this snail has just colonized water
Table 4 Estimates of univariate generalized linear mixed effects model

\begin{tabular}{|c|c|c|c|c|}
\hline \multirow[t]{2}{*}{ Variables } & \multirow[t]{2}{*}{ Posterior mean } & \multicolumn{2}{|c|}{ 95\% Credible interval } & \multirow[t]{2}{*}{ pMCMC } \\
\hline & & Lower & Upper & \\
\hline \multicolumn{5}{|c|}{ Landscape and climatic variables } \\
\hline Altitude (m) & 0.04 & -0.06 & 0.14 & 0.412 \\
\hline NDVI & 42.37 & 7.80 & 86.28 & 0.007 \\
\hline MAP (mm) & 0.02 & -0.02 & 0.05 & 0.294 \\
\hline $\operatorname{MAT}\left({ }^{\circ} \mathrm{C}\right)$ & -1.41 & -8.58 & 4.95 & 0.728 \\
\hline $\operatorname{MaxTWM}\left({ }^{\circ} \mathrm{C}\right)$ & -7.45 & -17.35 & -0.14 & 0.024 \\
\hline $\operatorname{MinTCM}\left({ }^{\circ} \mathrm{C}\right)$ & -0.01 & -4.45 & 4.92 & 0.962 \\
\hline MTWQ $\left({ }^{\circ} \mathrm{C}\right)$ & -5.00 & -14.12 & 3.05 & 0.205 \\
\hline MTCQ $\left({ }^{\circ} \mathrm{C}\right)$ & 0.77 & -4.40 & 6.68 & 0.734 \\
\hline \multicolumn{5}{|l|}{ Water variables } \\
\hline $\mathrm{pH}$ & -2.52 & -13.28 & 8.92 & 0.584 \\
\hline $\log _{10}(\mathrm{TN})$ & -3.12 & -11.41 & 6.63 & 0.454 \\
\hline $\log _{10}\left(\mathrm{NO}_{x}^{-}\right)$ & -3.14 & -10.19 & 1.97 & 0.2 .97 \\
\hline $\log _{10}\left(\mathrm{NH}_{3} \mathrm{~N}\right)$ & 0.59 & -5.00 & 6.67 & 0.890 \\
\hline $\log _{10}(T P)$ & 1.07 & -2.46 & 4.44 & 0.522 \\
\hline $\log _{10}(C O D)$ & 0.41 & -9.84 & 10.46 & 0.873 \\
\hline DO & 3.89 & 0.59 & 7.56 & 0.001 \\
\hline $\log _{10}(E C)$ & 0.26 & -11.89 & 11.18 & 0.969 \\
\hline $\log _{10}(\mathrm{Ca})$ & 3.75 & -4.46 & 9.35 & 0.239 \\
\hline $\mathrm{Mg}$ & -23.69 & -34.46 & -12.69 & $<0.001$ \\
\hline $\log _{10}(Z n)$ & 1.66 & -4.94 & 7.94 & 0.598 \\
\hline $\log _{10}(M n)$ & 8.33 & -3.81 & 21.57 & 0.182 \\
\hline \multicolumn{5}{|c|}{ Sediment variables } \\
\hline pH_S & -4.08 & -10.01 & 0.73 & 0.125 \\
\hline $\log _{10}\left(E C \_s\right)$ & 4.59 & -5.13 & 16.16 & 0.380 \\
\hline $\log _{10}(T O C)$ & -0.10 & -16.44 & 12.34 & 0.962 \\
\hline $\log _{10}\left(\mathrm{Cu} \_\mathrm{s}\right)$ & -0.76 & -2.06 & 3.72 & 0.577 \\
\hline $\log _{10}\left(Z n \_s\right)$ & 6.22 & 0.88 & 12.66 & 0.014 \\
\hline $\log _{10}\left(M n \_s\right)$ & 0.68 & -4.01 & 6.53 & 0.843 \\
\hline $\log _{10}\left(C d \_s\right)$ & 0.79 & -1.53 & 3.68 & 0.597 \\
\hline $\log _{10}\left(P b \_s\right)$ & -0.60 & -2.68 & 1.23 & 0.555 \\
\hline
\end{tabular}

Table 5 Results of the multivariate generalized linear mixed effects model

\begin{tabular}{lcccc}
\hline Variables & $\begin{array}{c}\text { Posterior } \\
\text { mean }\end{array}$ & \multicolumn{2}{l}{$95 \%$ Credible interval } & pMCMC \\
\cline { 3 - 4 } & Lower & Upper & \\
\hline Landscape and climatic variables & & & \\
MaxTWM $\left({ }^{\circ} \mathrm{C}\right)$ & -18.75 & -28.99 & -6.77 & $<0.001$ \\
$\begin{array}{l}\text { Sediment variables } \\
\log _{10}(\mathrm{Zn} \text { ns })\end{array}$ & 13.87 & 8.03 & 20.28 & $<0.001$ \\
\hline
\end{tabular}


habitats in Shenzhen and nearby. High habitat suitability of $B$. straminea has been predicted in southern parts of Guangxi, Pearl River Delta areas of Guangdong, Hong Kong and restricted areas of North Taiwan $[12,19]$. This prediction was only based on the distribution data in China and could be biased by the stage of invasion [20]. It is unknown how wide a geographical range this snail species may be able to colonize. In this respect, we compared the landscape and climatic characteristics between sites currently with and without $B$. straminea. Maximum temperature of the warmest month was found to be lower for locations where B. straminea was present. Air temperature has a direct impact on surface water temperature. Above-optimal water temperature can inhibit the fecundity and survival of adult snails and growth of juvenile ones [21]. Nevertheless, such unfavorable water temperature can be shunned by hiding under vegetation or moving deeper into the water $[6,21]$. No differences in altitude, NDVI, precipitation and other temperature-related variables were found.

Within freshwater environments, physical and chemical properties of water and sediment are key factors for the survival of organisms [22, 23]. Type of water bodies and water quality have been suggested as important determinants influencing snail distribution [6]. Biomphalaria spp. abundance was found to be positively correlated with conductivity, hardness, calcium, nitrites plus nitrates, ammonium, and bicarbonates in rice fields in Argentina, but not with phosphates, $\mathrm{pH}$ or soil granulometry [24]. We found no significant differences between colonized and non-colonized areas in water $\mathrm{pH}$, electrical conductivity, total nitrogen, nitrate and nitrites, ammoniacal nitrogen, total phosphorus, chemical oxygen demand and dissolved oxygen. There was no difference in sediment $\mathrm{pH}$, electrical conductivity, and total organic carbon.

Metals also play an essential role in the survival, growth, and reproduction of Biomphalaria snails. Calcium has been associated with the growth of B. glabrata [25]. A high magnesium-to-calcium ratio was observed in streams where aquatic snails were absent [26]. Acute exposures to heavy metals (cadmium, lead and arsenic) were found to affect the reproduction of B. glabrata in terms of egg laying, hatching time and embryonic survival [27]. Low zinc concentrations were able to suppress the egg hatching, growth and sexual maturity of B. glabrata [28]. In the present study, none of the metals in the water differed between sites with and without $B$. straminea. Sediment zinc was higher at places with $B$. straminea. This phenomenon suggested that this snail has successfully adapted to urban water bodies polluted by industrial waste, domestic sewage, traffic and runoff.

This study has several limitations. B. straminea was identified using morphological straits, and we were unable to examine the phylogenetic relationships of Biomphalaria snail populations captured. Besides, the infection status of $S$. mansoni was not detected among the specimens. To date, there has been no evidence for $S$. mansoni in samples collected in Hong Kong, Shenzhen and Dongguan in the mainland China [10]. Both lab-reared and field-captured B. straminea snails from a stream in Luohu District of Shenzhen seemed incompatible with the S. mansoni Puerto Rican strain [29]. The compatibility between the snail vector $B$. straminea and $S$. mansoni varied among different geographical regions [29]. Further studies are warranted to confirm the compatibility between $B$. straminea snails sampled throughout the Zhujiang River Basin and S. mansoni strains from the other endemic regions. Additionally, since the malacological survey spanned over a year, seasonal variations of the water and sediment measurements were inevitable. To address the resultant seasonal effects, we included sampling month as a random effect term in the GLMM. Finally, other factors, including current velocity, the presence of predators and competing snails and microbial composition of the water were not analyzed in our study. Future survey should incorporate such measurements. It is worth mentioning that the presence or abundance of snails does not depend on a single environmental factor, but is rather the result of a complex interaction of multiple habitat factors [22]. Therefore, our results should be interpreted with caution.

\section{Conclusions}

This study revealed the presence of B. straminea in Shenzhen and Dongguan of Guangdong Province, China. Significant differences were found in maximum temperature of the warmest month and sediment zinc between sites with and without $B$. straminea. Our results have important implications in prioritizing monitoring efforts to regions most at risk.

\section{Additional files}

Additional file 1: Multilingual Abstracts in the five official languages of the United Nations. (PDF 475 kb)

Additional file 2: Table S1. Physicochemical parameters measured and relevant analytical methods in this study. (DOCX 24 kb)

\section{Abbreviations \\ Ca: Calcium; Cd: Cadmium; COD: Chemical oxygen demand; Cr: Chromium; Cu: Copper; CV: Coefficient of variation; DO: Dissolved oxygen; EC: Electrical conductivity; Fe: Iron; LOD: Limit of detection; Mg: Magnesium; Mn: Manganese; NDVI: Normalized difference vegetation index; $\mathrm{NH}_{3} \_\mathrm{N}$ : Ammoniacal nitrogen; Ni: Nickel; $\mathrm{NO}_{x}$ : Nitrate and nitrites; Pb: Lead; SD: Standard deviation; TN: Total nitrogen; TOC: Total organic carbon; TP: Total phosphorus; Zn: Zinc}

\section{Funding}

This work was supported by the National Research and Development Plan of China (No. 2016YFC1200500). 


\section{Availability of data and materials}

Please contact the corresponding authors for data requests.

\section{Authors' contributions}

$Y Y, Z H D$, and YBZ conceived and designed the study. YY, SYH, ZHD, and YBZ organized the fieldwork. YY, SYH and FQP collected the data. YY performed the statistical analyses. YY, YC, QWJ, ZHD and YBZ coordinated, drafted and revised the manuscript. All authors read and approved the final manuscript.

\section{Ethics approval and consent to participate}

This field investigation was performed in public areas without the need for approval by an institutional review board.

\section{Consent for publication}

Not applicable

\section{Competing interests}

The authors declare that they have no competing interests.

\section{Author details}

'Key Laboratory of Public Health Safety, Ministry of Education, Tropical Disease Research Center, Department of Epidemiology, School of Public Health, Fudan University, Shanghai, China. ${ }^{2}$ Guangdong Provincial Center for Disease Control and Prevention, WHO Collaborating Centre for Surveillance, Research and Training of Emerging Infectious Diseases, Guangzhou, Guangdong, China. ${ }^{3}$ School of Epidemiology and Public Health, Faculty of Medicine, University of Ottawa, Ottawa, Canada.

Received: 25 April 2018 Accepted: 11 October 2018 Published online: 05 November 2018

\section{References}

1. Colley DG, Bustinduy AL, Secor WE, King CH. Human schistosomiasis. Lancet. 2014;383:2253-64.

2. GBD 2016 Disease and Injury Incidence and Prevalence Collaborators. Global, regional, and national incidence, prevalence, and years lived with disability for 328 diseases and injuries for 195 countries, 1990-2016: a systematic analysis for the Global Burden of Disease Study 2016. Lancet. 2017;390:1211-59.

3. Attwood SW, Huo G, Qiu J. Update on the distribution and phylogenetics of Biomphalaria (Gastropoda: Planorbidae) populations in Guangdong Province, China. Acta Trop. 2015;141:258-70.

4. Wang W, Liang YS, Hong QB, Dai JR. African schistosomiasis in mainland China: risk of transmission and countermeasures to tackle the risk. Parasit Vectors. 2013;6:249.

5. Boissier J, Grech-Angelini S, Webster BL, Allienne JF, Huyse T, Mas-Coma S, et al. Outbreak of urogenital schistosomiasis in Corsica (France): an epidemiological case study. Lancet Infect Dis. 2016;16:971-9.

6. Rollinson D. Chapter 3: Biomphalaria natural history, ecology transmission, and Schistosome. In: Toledo R, Fried B, editors. Biomphalaria snails and larval trematodes. New York: Springer Science+Business Media; 2010. p. 57-80

7. Meier-Brook C. A snail intermediate host of Schistosoma mansoni introduced into Hong Kong. Bull World Health Organ. 1974;51:661.

8. Huang SY, Deng ZH, Chen PJ, Gao ST, Li XH, Zhang Y, et al. Discovery and spread of Biomphalaria straminea of schistosomiasis mansoni intermediate host in mainland of China. South China J Prev Med. 2014;40:521-5.

9. Hu R, Liu R, Hu N. China's belt and road initiative from a global health perspective. Lancet Glob Health. 2017;5:e752-3.

10. Zeng X, Yiu WC, Cheung KH, Yip HY, Nong W, He P, et al. Distribution and current infection status of Biomphalaria straminea in Hong Kong. Parasit Vectors. 2017;10:351.

11. Scholte RG, Carvalho OS, Malone JB, Utzinger J, Vounatsou P. Spatial distribution of Biomphalaria spp., the intermediate host snails of Schistosoma mansoni, in Brazil. Geospat Health. 2012;6:S95-101.

12. Yang $Y$, Cheng W, Wu X, Huang S, Deng Z, Zeng $X$, et al. Prediction of the potential global distribution for Biomphalaria straminea, an intermediate host for Schistosoma mansoni. PLOS Neg Trop Dis. 2018;12:e6548.

13. Fick SE, Hijmans RJ. WorldClim 2: new 1-km spatial resolution climate surfaces for global land areas. Int J Climatol. 2017;37:4302-15.

14. Wei T, Simko V. corrplot: visualization of a correlation matrix. Mmwr Morb Mortal Wkly Rep. 2016;52:145-51.
15. Had J. MCMC methods for multi-response generalized linear mixed models: the MCMCglmm R package. J Stat Softw. 2010;33:1-22.

16. Krivoruchko K. Empirical bayesian kriging implemented in ArcGIS geostatistical analyst. 2012. http://www.esri.com/NEWS/ARCUSER/1012/files/ ebk.pdf. Accessed 1 Apr 2018.

17. Lingscheid T, Kurth F, Clerinx J, Marocco S, Trevino B, Schunk M, et al. Schistosomiasis in European travelers and migrants: analysis of 14 years TropNet surveillance data. Am J Trop Med Hyg. 2017;97:567-74.

18. Song L, Wu X, Sacko M, Wu Z. History of schistosomiasis epidemiology, current status, and challenges in China: on the road to schistosomiasis elimination. Parasitol Res. 2016:115:4071-81.

19. Habib MR, Guo Y, Lv S, Gu W, Li X, Zhou X. Predicting the spatial distribution of Biomphalaria straminea, a potential intermediate host for Schistosoma mansoni, in China. Geospat Health. 2016;11:453.

20. Václavík T, Meentemeyer RK. Equilibrium or not? Modelling potential distribution of invasive species in different stages of invasion. Divers Distrib. 2012;18:73-83.

21. Barbosa FS, Barbosa CS. The bioecology of snail vectors for schitosomiasis in Brazil. Cadernos De Saúde Pública. 1994;10:200-9.

22. Utzinger J, Mayombana C, Mez K, Tanner M. Evaluation of chemical and physical-morphological factors as potential determinants of Biomphalaria pfeifferi (Krauss, 1848) distribution. Mem Inst Oswaldo Cruz. 1997;92:323-8.

23. Dalu T, Wasserman RJ, Tonkin JD, Mwedzi T, Magoro ML, Weyl OLF. Water or sediment? Partitioning the role of water column and sediment chemistry as drivers of macroinvertebrate communities in an austral south African stream. Sci Total Environ. 2017;607-608:317-25.

24. Rumi A, Hamann MI. Potential schistosome-vector snails and associated trematodes in ricefields of Corrients province, Argentina: preliminary results. Mem Inst Oswaldo Cruz. 1990;85:321-8.

25. Kloos H, Passos LKJ, LoVerde P, Oliveira RC, Gazzinelli A. Distribution and Schistosoma mansoni infection of Biomphalaria glabrata in different habitats in a rural area in the Jequitinhonha Valley, Minas Gerais, Brazil: environmental and epidemiological aspects. Mem Inst Oswaldo Cruz. 2004;99:673-81.

26. Harrison AD, Nduku W, Hooper AS. The effects of a high magnesium-tocalcium ratio on the egg-laying rate of an aquatic planorbid snail, Biomphalaria pfeifferi. Ann Trop Med Parasitol. 1966;60:212.

27. Ansaldo M, Nahabedian DE, Di Fonzo C, Wider EA. Effect of cadmium, lead and arsenic on the oviposition, hatching and embryonic survival of Biomphalaria glabrata. Sci Total Environ. 2009;407:1923-8.

28. Münzinger A, Guarducci ML. The effect of low zinc concentrations on some demographic parameters of Biomphalaria glabrata (say), mollusca: gastropoda. Aquat Toxicol. 1988;12:51-61.

29. Qu G, Wang W, Lu X, Dai J, Li X, Liang Y. Evaluating the risk of Schistosoma mansoni transmission in mainland China. Parasitol Res. 2016;115:1-03.
Ready to submit your research? Choose BMC and benefit from:
- fast, convenient online submission
- thorough peer review by experienced researchers in your field
- rapid publication on acceptance
- support for research data, including large and complex data types
- gold Open Access which fosters wider collaboration and increased citations
- maximum visibility for your research: over $100 \mathrm{M}$ website views per year
At BMC, research is always in progress.
Learn more biomedcentral.com/submissions 